\title{
Histology and Histometric Anatomy of the Male Reproductive System of Bat (Eidolon helvum)
}

\author{
A. Danmaigoro, ${ }^{1}$ J. E. Onu, ${ }^{1}$ M. L. Sonfada, ${ }^{1}$ M. A. Umaru, ${ }^{2}$ and F. O. Oyelowo ${ }^{1}$ \\ ${ }^{1}$ Department of Veterinary Anatomy, Faculty of Veterinary Medicine, Usmanu Danfodiyo University, PMB 2346, Sokoto, Nigeria \\ ${ }^{2}$ Department of Theriogenology and Animal Production, Faculty of Veterinary Medicine, Usmanu Danfodiyo University, \\ $P M B$ 2346, Sokoto, Nigeria
}

Correspondence should be addressed to A. Danmaigoro; aburamcy@yahoo.com

Received 19 February 2014; Accepted 20 March 2014; Published 10 April 2014

Academic Editor: Francesco Cappello

Copyright (C) 2014 A. Danmaigoro et al. This is an open access article distributed under the Creative Commons Attribution License, which permits unrestricted use, distribution, and reproduction in any medium, provided the original work is properly cited.

\begin{abstract}
The male reproductive system of fruit bat (Eidolon helvum) was studied histologically using light microscope. Thirty males (17 adults and 13 juveniles) were captured using net, weighed, aged using relative ossification of the wing bone, and dissected and reproductive tissue was processed for histomorphometry. On the basis of histological sections, the structures of a pair of testis containing the seminiferous tubules of adults were compacted in organization with spermatogenic cells. The epididymis has a thinner muscular region than the vas deferens with longitudinal folds on the mucosal lining. Two portions were observed in the prostate gland, while seminal vesicle has numerous trabeculae and bulbourethral gland was observed to have multiacini. There was increase in thickness of muscular region, epithelial height, and luminal diameter of epididymis and vas deferens between adults and juveniles. This work has documented the histology of the male reproductive system in bats, and ultrastructure and histochemistry are recommended for further insight into the reproductive biology.
\end{abstract}

\section{Introduction}

Bats (Chiroptera) are among the most diverse and widely distributed groups of mammals and can be found in most continents [1]. There are around 1,150 species of bats. Bats are second only to rodents in numbers of living genera and species, which represents nearly a quarter of all the species of mammals on earth, and the majority live in tropical and semitropical regions [1].

Bats are the only flying mammals and they have a wide range of feeding and roosting habits, social behaviours, and reproductive strategies [2]. Diversity in their biology makes bats not only a fascinating group of animals to study but also a difficult one.

They are unique in their agility (potential for longdistance travel) and often aggregate in very large colonies, and these activities aid in the spread of diseases [3]. They are natural reservoir for a large number of zoonotic pathogens such as rabies virus [4], coronavirus [5], and Henipavirus, that is, nipah virus, hendra virus [6], and possibly Ebola virus $[7,8]$.

Eidolon helvum are commonly found in moist and dry tropical rain forest, including evergreen forest habitats in the form of coastal (including mangrove) and riverine forest, through moist and dry savanna and mosaics of these and similar habitat types. Populations can persist in modified habitats and the species is often recorded in urban areas, such as wooded city parks [9].

Some works on the physiology, histology, breeding, and pathology of reproductive organs of the female bats [10-14] have been reported in different countries including Nigeria. Though the histology of the male reproductive system varies widely among different mammalian species [15] a good understanding of the reproductive biology, particularly the anatomy of the male reproductive system, is very vital [16].

The reproductive tract of male mammals generally consists of the testes and associated epididymis, vasa deferentia, accessory sex gland complex, urethra, and penis. 
The accessory sex gland complex consists of ampullary gland, prostate, urethra, Cowper's glands, and seminal vesicles [17]. However not all glands are present in every mammalian order [16] and in the Chiroptera this is revealed in a study by [18] on Rhinolophus capensis. The main function of the male reproductive system is the production and storage of spermatozoa and their transport in a viable stage state into the reproductive tract of the female [17].

Histologically, the male reproductive tracts consist of the paired testes and accessory sex glands which follows the normal mammalian pattern, for example, in Pteropodidae $[19,20]$.

The increase in population of bats in human dwelling could be linked to reemerging zoonotic diseases, in which, when its reproductive morphology is studied, the result could be used in intervening in its reproductive cycle. Although E. helvum is found to be widely distributed in Northwestern Nigeria, little is known about its male reproductive histology. It is, therefore, reasonable to study the normal histology of the reproductive system of this species, which could serve as a baseline data in further study of the species.

\section{Materials and Methods}

2.1. Source of Bats. Bats were sourced from Zuru town, Kebbi State in Northwestern Nigeria. The capturing process involved the use of hand nets with extendable poles, during daytime at the roosts of the bats. The bats were held in plastic cages $(2.9 \mathrm{~m}$ long $\times 2.4 \mathrm{~m}$ wide $\times 2.0 \mathrm{~m}$ high $)$ and leaves were hung on the ceilings of the cages to provide roosts for the bats and transported to the Veterinary Anatomy Laboratory of Usmanu Danfodiyo University, Sokoto, Nigeria.

2.2. Bat Identification. Species were identified at the Zoology Laboratory Unit, Department of Biological Sciences, Usmanu Danfodiyo University, Sokoto, Nigeria. The following features were used for identification of the species as described by [21].

2.3. Aging and Sexing. In these studies, bats were simply categorized into age groups, juvenile and adult [22]. Juveniles can be distinguished from adults by the lack of ossification in the plates in the joints of finger bones, which can easily be seen if the joints are illuminated from behind. The cartilaginous ends of the bones in juveniles appear paler and more translucent than the joints of adults [22]. The joints of adults are also more rounded and knuckle-like than those of juveniles. Age estimation was achieved using relative ossification of the wing bones (4th metacarpal joint and phalanges) by transilluminating the wing of the bats using a torchlight, to visualize the cartilaginous zone of the long phalanges while the wing of the bat was being spread over a transparent solid plastic sheet lightened from below; this was done to distinguish between juvenile and adults as described by [23]. Sexing is straightforward in bats, due to the presence of a conspicuous penis in males [22].

2.4. Dissection and Sample Collection. Following anaesthesia, using chloroform (Prolabo, May and Baker, Nigeria), the bats were sacrificed by severing the jugular vein. They were then placed on their dorsal recumbency and a midline incision was made, extending from the xiphoid cartilage to the pubic symphysis. The peritoneum was reflected and intestine displaced to gain access to the reproductive tract as described by $[24]$.

2.5. Light Microscopy. The tissues (testes, vas deferens, epididymis, penis, and accessory sex glands) obtained were fixed in Bouin's solution for 48 hours, followed by preservation in $70 \%$ ethyl alcohol. They were dehydrated in series of graded ethanol $(70 \%, 80 \%, 90 \%$, and $100 \%)$, cleared in xylene, and embedded in paraffin wax. Serial sections at $5 \mu \mathrm{m}$ were cut and stained with haematoxylin and eosin for light microscopy.

2.6. Histometry. The following quantitative measurements were made from the sectioned tissues: thickness of the muscular region of the tubular structures and luminal diameter and epithelial height of the epididymis, vas deferens, seminiferous tubules, acinar diameter, epithelial height of the seminal vesicles, and prostate were measured using Moticam (DCM100, Resolution: 1.3 megapixels).

2.7. Photomicrographs. All micrographs were made using a light microscope with the aid of digital eyepiece (Moticam DCM100) attached to a light microscope (Leica, Germany) which conveyed the images to a personal computer (PC).

2.8. Data Analysis. The data were subjected to statistical analysis in which Student's $t$-test was used to check the significant differences between the histometric values of the structures (testes, epididymides, vas deferens, and accessory sex gland) with the ages and paired structures, where probability of $<$ 0.05 was considered to be significant.

\section{Results}

3.1. Histology. Histologically, seminiferous tubules were observed showing Sertoli cells (sustentacular cells) and different spermatogenic cell lineages. Spermatogenic cells observed include spermatogonia, primary and secondary spermatocytes, and round and elongating spermatids; interstitium consisting of connective tissue, blood vessels, and Leydig cells were also observed (Figure 1).

The mucosa of epididymis is composed of pseudostratified columnar epithelium with extensive stereocilia, connective tissue, and smooth muscles. Basal cells were observed in the epithelium. The basal cell is firmly opposed to the basal lamina and does not reach the tubular lumen but has an elongated nucleus and more basophilic cytoplasm than columnar epithelia cells and with more spermatozoa in the lumen of the cauda epididymis (Figure 2).

It was observed that muscular layer of the vas deferens was thicker with longitudinal folds on the mucosal lining, resulting in an irregular outline of the lumen. The mucosa was seen to be lined with pseudostratified columnar epithelium as seen in the epididymis (Figure 3 ). 


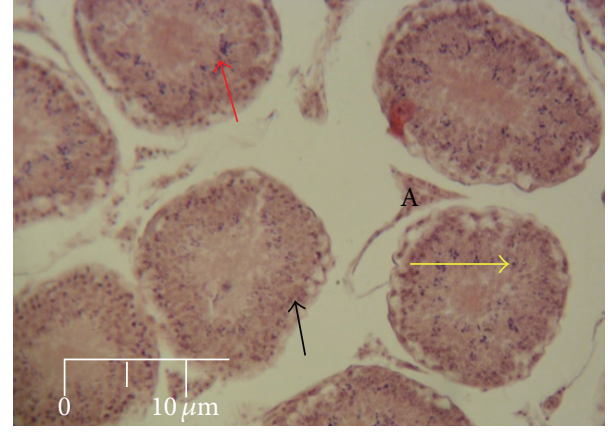

FIGURE 1: Photomicrograph of seminiferous tubules (cross section) showing spermatogenic cells. Spermatogonia (black arrow), spermatocytes (yellow arrow), spermatid (red arrow), and Leydig cell (A) $(\mathrm{H} \& \mathrm{E} \times 100)$.

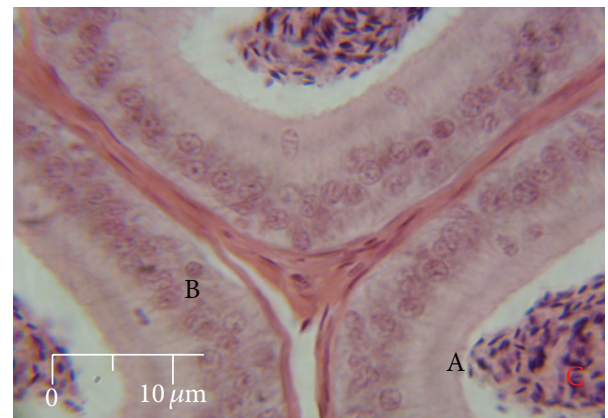

Figure 2: Photomicrograph of the cauda epididymis showing the mucosa lined by pseudostratified columnar epithelium with stereocilia (A), basal cells at the lamina propria (B), and presence of spermatozoa in the lumen $(\mathrm{C})(\mathrm{H} \& \mathrm{E} \times 100)$.

In the penis, bundles of muscle fascicules of corpus cavernosum, corpus cavernosum glandis, and urethra were observed and all are enclosed by thin tunica albuginea. In the glans, the corpora cavernosa bend ventrally and end at the proximal part of woven fibrocartilaginous curve plate (os penis), which are in close vicinity with skeletal muscle and dorsal and deep blood vessels (Figure 4).

The prostate gland has two portions, the body and disseminate portion. The body was observed to have more connective tissues and smooth muscles and is more closely related to pelvic urethra. The duct systems were lined with pseudostratified columnar epithelium. The disseminate portion is more glandular with tubular alveolar type of gland, is dense in organization, and is lined by simple columnar epithelium as shown in Figure 5. Seminal vesicle has tubular secretory glands and was separated into lobules by connective tissue trabeculae and skeletal muscle septae. Multiple acini were observed with an irregular folded lumen and were lined by pseudostratified columnar secretory epithelium with basal cells as shown in Figure 6. The bulbourethral gland has connective tissue and numerous trabeculae that originate from the capsule and divides the gland into lobules and each lobule is formed by acini and the interstitium consists of loose connective tissue and smooth muscle. The acini were hexagonal in shape peripherally and circular to the centre filled with mucous secretory granules. The gland was

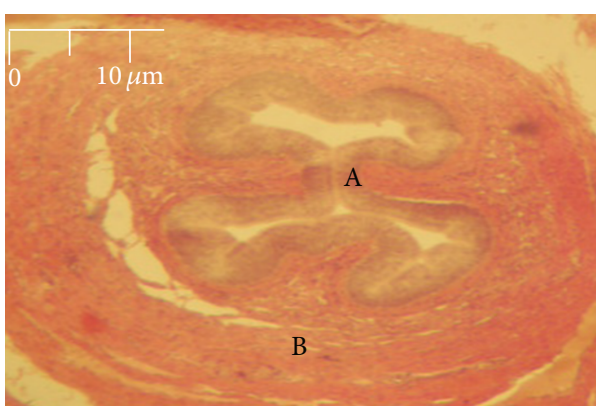

FIgURE 3: Photomicrograph of the vas deferens showing the longitudinal folds $(\mathrm{A})$ and muscular thickness $(\mathrm{B})(\mathrm{H} \& \mathrm{E} \times 100)$.

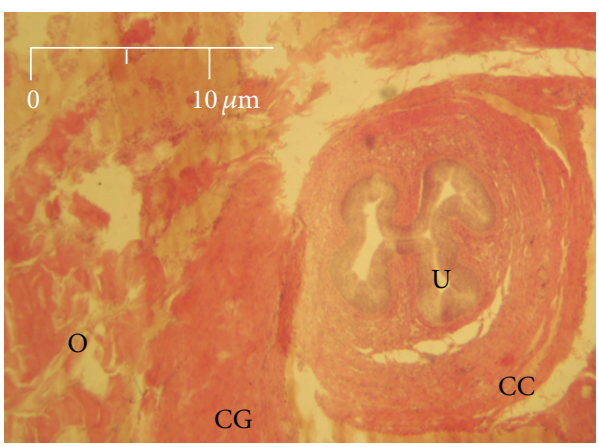

Figure 4: Photomicrograph of the penis showing corpus cavernosum $(\mathrm{CC})$, corpus glandis $(\mathrm{CG})$, os penis $(\mathrm{O})$, and urethra $(\mathrm{U})$ $(\mathrm{H} \& \mathrm{E} \times 100)$.

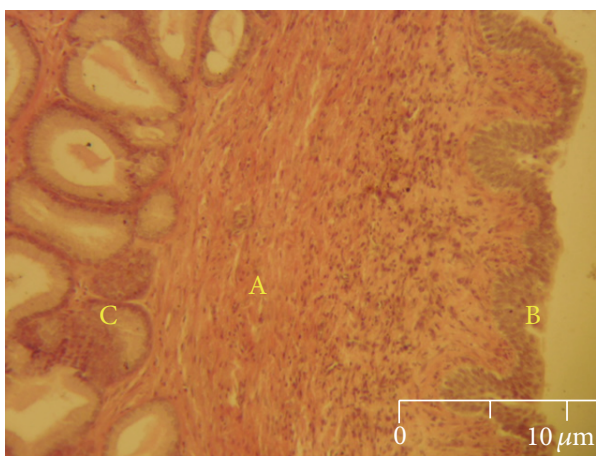

FIgURE 5: Photomicrograph of the prostate gland showing body (A), pelvic urethra mucosa (B), and disseminate portion with tubular alveolar gland $(\mathrm{C})(\mathrm{H} \& \mathrm{E} \times 400)$.

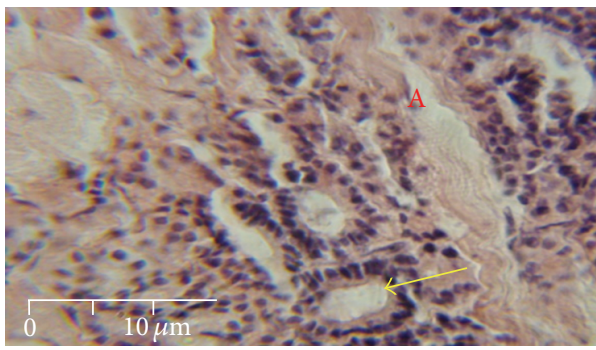

FIgURE 6: Photomicrograph of the seminal vesicle showing its division into lobules by trabecula $(\mathrm{A})$ and pseudostratified columnar epithelium with basal cells (yellow arrow) $(\mathrm{H} \& \mathrm{E} \times 400)$. 


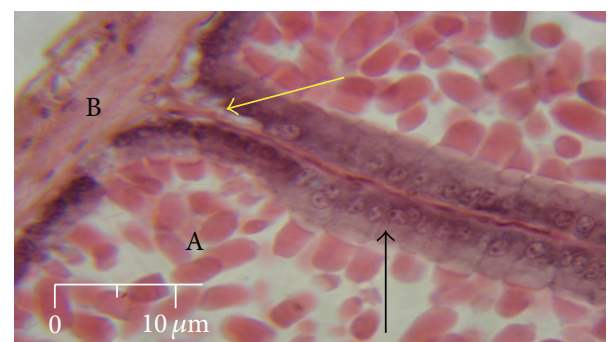

FIGURE 7: Photomicrograph of the bulbourethral gland showing its division into lobules by trabecula (yellow arrow) and its secretory columnar epithelium (black arrow) with mucous secretory granules (A) in the lumen and connective tissue $(B)(H \& E \times 400)$.

observed lined by secretory columnar epithelium. All the epithelial cells were characterized by a nucleus in basal position (Figure 7).

3.2. Histometry. The average diameter of the seminiferous tubules was $110.2 \pm 8.06 \mu \mathrm{m}$ in the adults and $85.5 \pm 5.01 \mu \mathrm{m}$ in juveniles (Table 1). The average thickness of the muscular region, mean epithelial height, and luminal diameter of the epididymis in both adult and juveniles were $10.19 \pm 0.01 \mu \mathrm{m}$, $6.41 \pm 0.02 \mu \mathrm{m}$, and $41.84 \pm 0.3 \mu \mathrm{m}$ and $8.13 \pm 0.01 \mu \mathrm{m}$, $4.33 \pm 0.02 \mu \mathrm{m}$, and $38.23 \pm 0.15 \mu \mathrm{m}$, respectively, as shown in Table 2 . The average thickness of the muscular region, mean epithelial height, and mean luminal diameter in both adult and juvenile vas deferens were $76.32 \pm 0.22,41.17 \pm 0.09 \mu \mathrm{m}$, and $72.21 \pm 0.26 \mu \mathrm{m}$ and $66.14 \pm 0.10 \mu \mathrm{m}, 30.50 \pm 0.08 \mu \mathrm{m}$, and $64.83 \pm 0.30 \mu \mathrm{m}$, respectively, as shown in Table 1 .

The prostate gland mean acini diameter of $31.45 \pm 0.25 \mu \mathrm{m}$ and $20.42 \pm 0.08 \mu \mathrm{m}$ was found in adult and juvenile, respectively (Table 2). The trabecular connective tissue thickness of seminal vesicle was $11.18 \pm 0.09 \mu \mathrm{m}$ in adult and $12.43 \pm$ $0.10 \mu \mathrm{m}$ in juveniles (Table 2). The acini diameter was $28.54 \pm$ $0.5 \mu \mathrm{m}$ in adult and $22.43 \pm 0.48 \mu \mathrm{m}$ in juvenile (Table 2) with an average epithelium height of $30.49 \pm 0.02 \mu \mathrm{m}$ in adult while in juvenile it was $12.3 \pm 0.03 \mu \mathrm{m}$ (Table 2).

\section{Discussion}

The microscopic structures of the reproductive tract and accessory sex glands in this study have great similarity to that of other mammals. This finding is in agreement with the report of [25] that microscopic structures of the reproductive organs in bat follow the normal mammalian pattern.

The different spermatogenic cells observed in the seminiferous tubules were similar to findings reported by [26] in Rhinopoma kinneari bat where cyclic process of spermatogenesis was studied. The presence of sperm cells in the seminiferous tubules reaffirms the findings of the sperm cell competition in other mammals and bats due to their presence in the epididymis as reported by [27]. The presence of sperm cells in the cauda epididymis was also reported by [25], the cauda epididymis serving as a reservoir for the storage of sperm cells. The epididymal corpus is characterized by a greater epithelial height and few spermatozoa in the lumen.
These features suggest a fast transit of spermatozoa in this segment.

The vas deferens has been described as a heavily muscular tube in humans as reported by $[28,29]$ and possesses narrow and irregular lumen. The thickness of the wall, luminal diameter, and longitudinal folds in the lumen of the vas deferens in this study were similar to the reports of [28] in rat and humans. The authors reported that the thickness of the wall of the vas deferens was found to be almost equal to the diameter of the lumen with irregular longitudinal folds. The irregularity in the shape of the lumen has been attributed to be the effect of contraction of smooth muscle in the tunica mucosa.

The large amount of muscular region in vas deferens is attributed to the role it plays in conducting fluid produced by the testis and epididymis. However, the epithelial lining type observed was similar to the findings of $[30,31]$ that both epididymis and vas deferens ducts were lined by pseudostratified columnar epithelium with stereocilia and simple columnar epithelium, respectively.

The penis as seen in this study was similar to the findings of [32] in bat (Cynopterus sphinx gangeticus) where the os penis and corpus cavernosum are connected by a layer of fibrocartilage, suggesting the presence of os penis. It has been suggested that the os penis facilitates penetration and acts as a wedge to open the female vaginal tract [32] and enhances sperm deposition and transportation during mating.

Prostate gland presents two lobules joined by an isthmus which do not completely surround the urethra. This observation is different from the report of [32] where the gland is formed by two lateral lobules, dorsal and ventral. This observation is also contrary to the report in rabbit in which the prostatic complex is formed by a proprostate, a prostate, and paraprostate [33].

The connective tissue and smooth muscle fibre that make up the trabeculae observed dividing the vesicular gland into lobules were similar to the histological appearance reported by [34] in African greater cane rat that the vesicular gland is covered with thin connective tissue capsule with bundles of smooth muscle fibres forming the trabeculae that divide the gland into lobules.

Tubuloalveolar gland type was observed in the bulbourethral gland as described by [35]. The epithelial lining types observed on the acini were similar to those observed by [36] in Indian goat. The gland is surrounded by layers of skeletal muscle fibres, which suggest that muscular contraction facilitates the expulsion of secretion, as has been described in three Australian vespertilionid bats by [37].

4.1. Histometry. Histometrically, the results obtained from the study of the seminiferous tubules differ from the report of [37] which reported $183.0 \mu \mathrm{m}$ in Australian vespertilionid bat; this variation could be attributed to mating system and intermale sperm competition. The histometric parameters on the epididymis and vas deferens in adult on muscular region thickness, epithelial height, epithelial cell thickness, and luminal diameter were similar to the reports of [32] in 
TABLE 1: Histometric measurement on the testis, epididymis, and vas deferens of both adult and juvenile bats.

\begin{tabular}{lccc}
\hline Parameter $(\mu \mathrm{m})$ & Adult $(n=17)$ & Juvenile $(n=13)$ & \\
\hline Testis & & $85.5 \pm 5.01$ & \\
$\quad$ Seminiferous tubular diameter & $110.2 \pm 8.06$ & $8.13 \pm 0.01$ & 0.009 \\
Epididymis & & $4.33 \pm 0.02$ & 0.0003 \\
$\quad$ Thickness of the muscular region & $10.19 \pm 0.01$ & $38.23 \pm 0.15$ & 0.0001 \\
Epididymal epithelial height & $6.41 \pm 0.02$ & & 0.0528 \\
$\quad$ Epididymal luminal diameter & $41.84 \pm 0.30$ & $66.14 \pm 0.10$ & $30.50 \pm 0.08$ \\
Vas deferens & & $64.83 \pm 0.30$ & 0.0002 \\
Thickness of the muscular region & $76.32 \pm 0.22$ & & 0.0001 \\
Epithelial height & $41.17 \pm 0.09$ & & \\
Luminal diameter & $72.21 \pm 0.26$ & &
\end{tabular}

The values are expressed as mean \pm SEM. $P<0.05$ is considered significant.

TABLE 2: Histometric measurement of prostate gland and seminal vesicle in both adult and juvenile bats.

\begin{tabular}{lccc}
\hline Parameter $(\mu \mathrm{m})$ & Adult $(n=17)$ & Juvenile $(n=13)$ & $P$ value \\
\hline $\begin{array}{l}\text { Prostate gland } \\
\quad \text { Acinar diameter }\end{array}$ & $31.45 \pm 0.25$ & $20.42 \pm 0.08$ & 0.002 \\
Seminal vesicle & & & \\
SV acinar diameter & $28.54 \pm 0.55$ & $22.43 \pm 0.48$ & 0.0001 \\
SV epithelial height & $30.49 \pm 0.02$ & $12.3 \pm 0.03$ & 0.0001 \\
SV trabecular CT & $11.18 \pm 0.09$ & $12.43 \pm 0.10$ & 0.0001 \\
\hline
\end{tabular}

The values are expressed as mean \pm SEM. $P<0.05$ is considered significant. SV: seminal vesicle; CT: connective tissue thickness.

(Cynopterus sphinx gangeticus) bat and that of [38] in rodent. Increase in acinar diameter of the prostate gland observed in bats as they age was similar to the findings reported by [36] in Australian vespertilionid bat which reported $108.08 \pm$ $10.3 \mu \mathrm{m}$ and this increase could be attributed to age of bats.

The seminal vesicles acinar diameter, epithelial height, and trabecular connective tissues thickness were in line with the report of [39] in Capra hircus (goat) which reported increase in acinar diameter of $67.07 \mu \mathrm{m}$ in adult and $51.53 \mu \mathrm{m}$ in prepuberty; this increase observed was attributed to age variation.

In conclusion, this work is probably the first histological study on the male reproductive system of the bat (Eidolon helvum) in Nigeria and has established a baseline data for the different segments of the male reproductive tract and accessory sex glands of the bat. It is expected that the results will guide further researches on the reproductive systems of the male bats.

It is suggested that the histochemical and ultrastructural studies of the male reproductive system are recommended for further insight into the reproductive biology of the species.

\section{Conflict of Interests}

The authors declare that there is no conflict of interests regarding the publication of this paper.

\section{Acknowledgment}

This study was supported by the Department of Veterinary Anatomy, Faculty of Veterinary Medicine, Usmanu Danfodiyo University, Sokoto, Nigeria.

\section{References}

[1] K. Riede, "Global register of migratory species-from global to regional scales," Final Report of the R\&D-Projekt 808-05-081, Federal Agency of Nature Conservation, 2004.

[2] Bat Conservation International Inc., "Bat facts and amazing trivia," Beaufortia, vol. 40, pp. 111-177, 1997.

[3] A. Danmaigoro, J. E. Onu, M. L. Sonfada, A. A. Umar, F. O. Oyelowo, and S. A. Hena, "Histomorphometry of the lower respiratory system of Straw Coloured Fruit Bat (Eidolon helvum)," Scientific Journal of Health, Safety and Environment, vol. 1, no. 4, pp. 75-80, 2013.

[4] K. A. McColl, N. Tordo, and A. A. Setién, "Bat lyssavirus infections," Revue Scientifique et Technique, vol. 19, no. 1, pp. 177196, 2000.

[5] W. Li, Z. Shi, M. Yu et al., "Bats are natural reservoirs of SARSlike coronaviruses," Science, vol. 310, no. 5748, pp. 676-679, 2005.

[6] K. Halpin, P. L. Young, H. E. Field, and J. S. Mackenzie, "Isolation of Hendra virus from pteropid bats: a natural reservoir of Hendra virus," Journal of General Virology, vol. 81, no. 8, pp. 1927-1932, 2000.

[7] E. M. Leroy, B. Kumulungui, X. Pourrut et al., "Fruit bats as reservoirs of Ebola virus," Nature, vol. 438, no. 7068, pp. 575576, 2005.

[8] C. Q. Choi, “Going to bat," Scientific American, vol. 294, no. 3, pp. 24-24, 2006.

[9] S. P. Mickleburgh, A. M. Hutson, and P. A. Racey, Old World Fruit Bats: An Action Plan for Their Conservation, IUCN, Gland, Switzerland, 1992.

[10] E. E. Okon, "Functional anatomy of the alimentary canal in the Fruit Bat, Eidolon helvum, and the insect bat, Tadarida nigeriae," Acta Zoologica, vol. 58, no. 2, pp. 83-93, 1977.

[11] F. Mutere, "Eidolon helvum. Revistied," in Proceedings of the 5th International Bat Research Conference, D. W. Gardner, Ed., pp. 145-150, Texas Press, Lubbock, Tex, USA, 1980.

[12] P. D. Heideman, K. P. Bhatnagar, F. K. Hilton, and F. H. Bronson, "Melatonin rhythms and pineal structure in a tropical bat, 
Anoura geoffroyi, that does not use photoperiod to regulate seasonal reproduction," Journal of Pineal Research, vol. 20, no. 2, pp. 90-97, 1996.

[13] A. O. Samson, A. A. Olusola, A. O. David et al., "Histological investigation of the pregnant and non-pregnant uterine limbs of the frugivorous bat (Eidolon helvum)," International Journal of Integrative Biology, vol. 3, no. 3, p. 172, 2008.

[14] S. A. Odukoya, O. A. Adeeyo, D. A. Ofusori et al., "Partial septate uterus and tubal implantation: a normal phenomenon in the Eidolon helvum," Scientific Research and Essays, vol. 4, no. 1, pp. 013-017, 2008.

[15] A. A. Thomson and P. C. Marker, "Branching morphogenesis in the prostate gland and seminal vesicles," Differentiation, vol. 74, no. 7, pp. 382-392, 2006.

[16] B. P. Setchell and W. G. Breed, "Anatomy, vasculature, and innervation of the male reproductive tract," in Knobil and Neill's Physiology of Reproduction, J. D. Neill, Ed., pp. 771-808, Elsevier, New York, NY, USA, 3rd edition, 2006.

[17] P. H. Krutzsch, "Male reproductive patterns in nonhibernating bats," Journal of Reproduction and Fertility, vol. 56, no. 1, pp. 333344, 1979.

[18] R. T. F. Bernard, "Seasonal changes in plasma testosterone concentrations and Leydig cell and accessory gland activity in the Cape horseshoe bat (Rhinolophus capensis)," Journal of Reproduction and Fertility, vol. 78, no. 2, pp. 413-422, 1986.

[19] A. Pal, "Studies on the male accessory complex and other associated glands in the Indian Fruit-Bat, Rousettus leschenaulti (Desmaret)," Journal of Current Bioscience, vol. 1, pp. 23-25, 1984.

[20] P. H. Krutzsch, R. A. Young, and E. G. Crichton, “Observations on the reproductive biology and anatomy of Rhinolophus megaphyllus (Chiroptera: Rhinolophidae) in eastern Australia," Australian Journal of Zoology, vol. 40, no. 5, pp. 533-549, 1992.

[21] S. Mickleburgh, A. M. Hutson, W. Bergmans, J. Fahr, and P. A. Racey, "Eidolon helvum," in IUCN 2011. IUCN Red List of Threatened Species. Version 2011.2, 2011, www.iucnredlist.org.

[22] T. Kunz, Ecological and Behavioral Methods for the Study of Bats, Smithsonian Institution Press, Washington, DC, USA, 1988.

[23] M. Sharifi, "Postnatal growth in Myotis blythii (Chiroptera, Vespertilionidae)," Mammalia, vol. 68, no. 4, pp. 283-289, 2004.

[24] A. W. Gustafson, "Male reproductive patterns in hibernating bats," Journal of Reproduction and Fertility, vol. 56, no. 1, pp. 317331, 1979.

[25] P. H. Krutzsch, "Anatomy, physiology and cyclicity of the male reproductive tract," in Reproductive Biology of Bats, E. G. Crichton and P. H. Krutzsch, Eds., pp. 91-250, Academic Press, London, UK, 2000.

[26] M. S. Singwi and S. B. Lall, "Spermatogenesis in the nonscrotal bat-Rhinopoma kinneari wroughton (Microchiroptera: Mammalia)," Acta Anatomica, vol. 116, no. 2, pp. 136-145, 1983.

[27] M. B. Fenton, "Sperm competition. The case of Vespertitionid and Rhonolopid bats," in Sperm Competition and the Evolution of Animal Mating Systems, R. L. Smith, Ed., pp. 573-587, Academic Press, Orlando, Fla, USA, 1984.

[28] A. A. Khan, M. T. Zaidi, and N. A. Faruqi, "Ductus deferens-a comparative histology in mammals," Journal of the Anatomical Society of India, vol. 52, no. 2, pp. 163-165, 2003.

[29] D. Cormack, "Hams histology," in Male Reproductive System, pp. 670-671, J. B. Lippinocott Company, Philladelphia, Pa, USA, 9th edition, 1987.
[30] C. C. I. Puga, M. R. Beguelini, A. C. Negrin et al., "Structure, histochemistry and ultrastructure of the male reproductive accessory glands in the neotropical flat-faced fruit-eating bat Artibeus planirostri (Chiroptera: Phyllostomidae)," Reproductive, Fertility and Development, vol. 25, no. 3, pp. 558-569, 2011.

[31] M. R. Beguelini, F. S. Bruno, J. L. Fábio, R. T. Sebastião, and M. V. Eliana, "Morphological and morphometric characteristics of the epididymis in the Neotropical bats Eumops glaucinus and Molossus molossus (Chiroptera: Molossidae)," Chiroptera Neotropical, vol. 16, no. 2, pp. 769-779, 2010.

[32] S. Vamburkar, "The male genital tract of the Indian megachiropteran bat Cynopterus sphinx gangeticus Anderson," Proceedings of the Zoological Society of London, vol. 130, pp. 57-77, 1957.

[33] W. Holtz and R. H. Foote, "The anatomy of the reproductive system in male Dutch rabbits (Oryctolagus cuniculus) with special emphasis on the accessory sex glands," Journal of Morphology, vol. 158, no. 1, pp. 1-20, 1978.

[34] A. O. Adebayo, B. O. Oke, and A. K. Akinloye, "Morphometry of accessory sex gland in the greater cane rat," Journal of Veterinary Anatomy, vol. 2, no. 2, pp. 41-51, 2009.

[35] J. A. Eurell and B. L. Frapper, Textbook of Veterinary Histology, Blackwell, Ames, Iowa, USA, 2007.

[36] P. Kundu, "Anatomical studies on the accessory male sex glands (gross and microscopic) of the Indian goat (Jamunapari and cross Jamunapari)," Indian Journal of Animal Health, vol. 19, pp. 151-153, 1980.

[37] D. J. Hosken, M. A. Blackberry, T. B. Stewart, and A. F. Stucki, "The male reproductive cycle of three species of Australian vespertilionid bat," Journal of Zoology, vol. 245, no. 3, pp. 261270, 1998.

[38] P. Massányi, A. Jančová, and V. Uhrín, "Morphometric study of male reproductive organs in the rodent species Apodemus sylvaticus and Apodemus flavicollis," Bulletin of the Veterinary Institute in Pulawy, vol. 47, no. 1, pp. 133-138, 2003.

[39] P. Archana, R. S. Katiyar, D. N. Sharma, and M. M. Farooqui, "Gerentological studies on the gross and histomorphology of the vesicular gland of Gaddi goat (Capra hircus)," International Journal of Morphology, vol. 27, no. 1, pp. 13-20, 2009. 

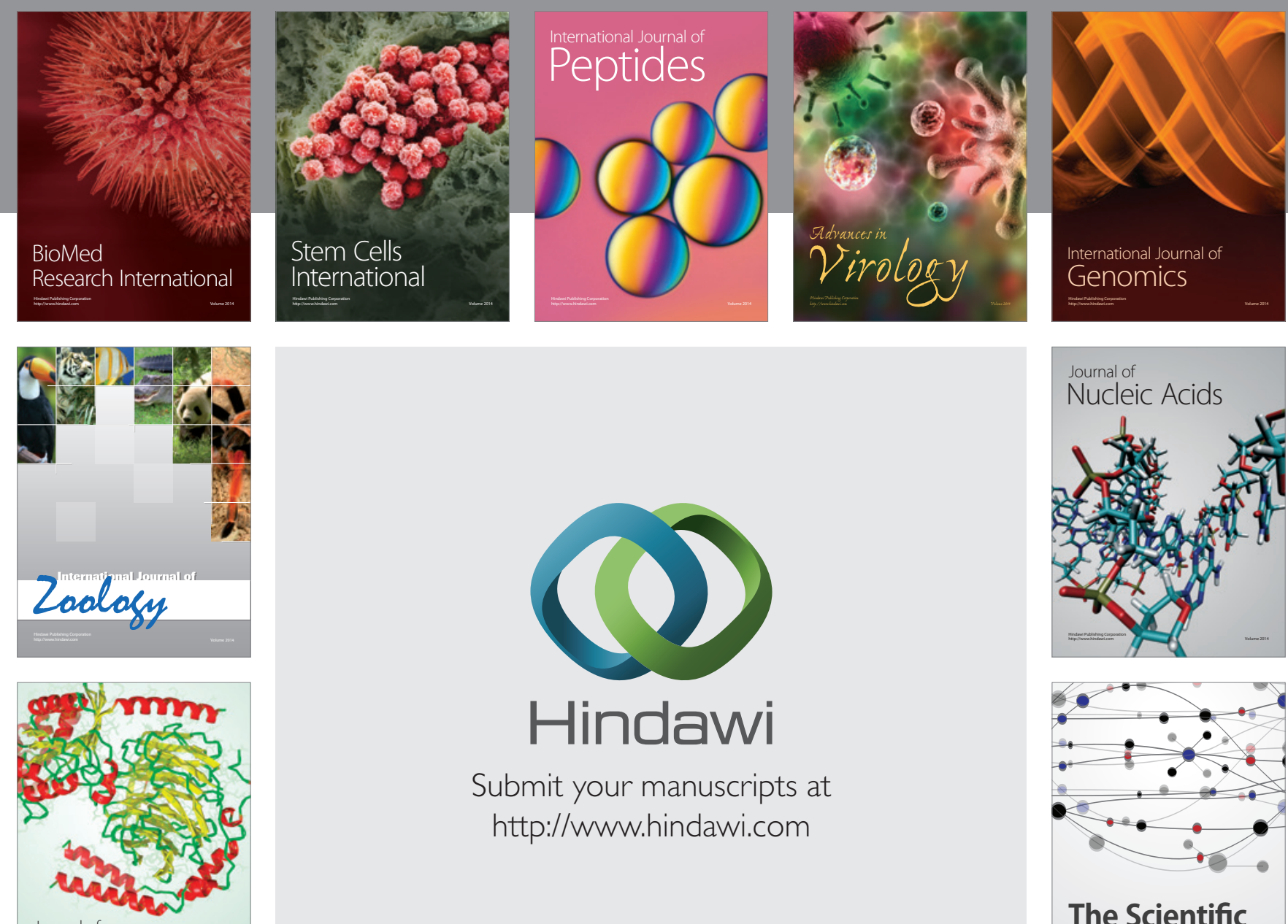

Submit your manuscripts at

http://www.hindawi.com

Journal of
Signal Transduction
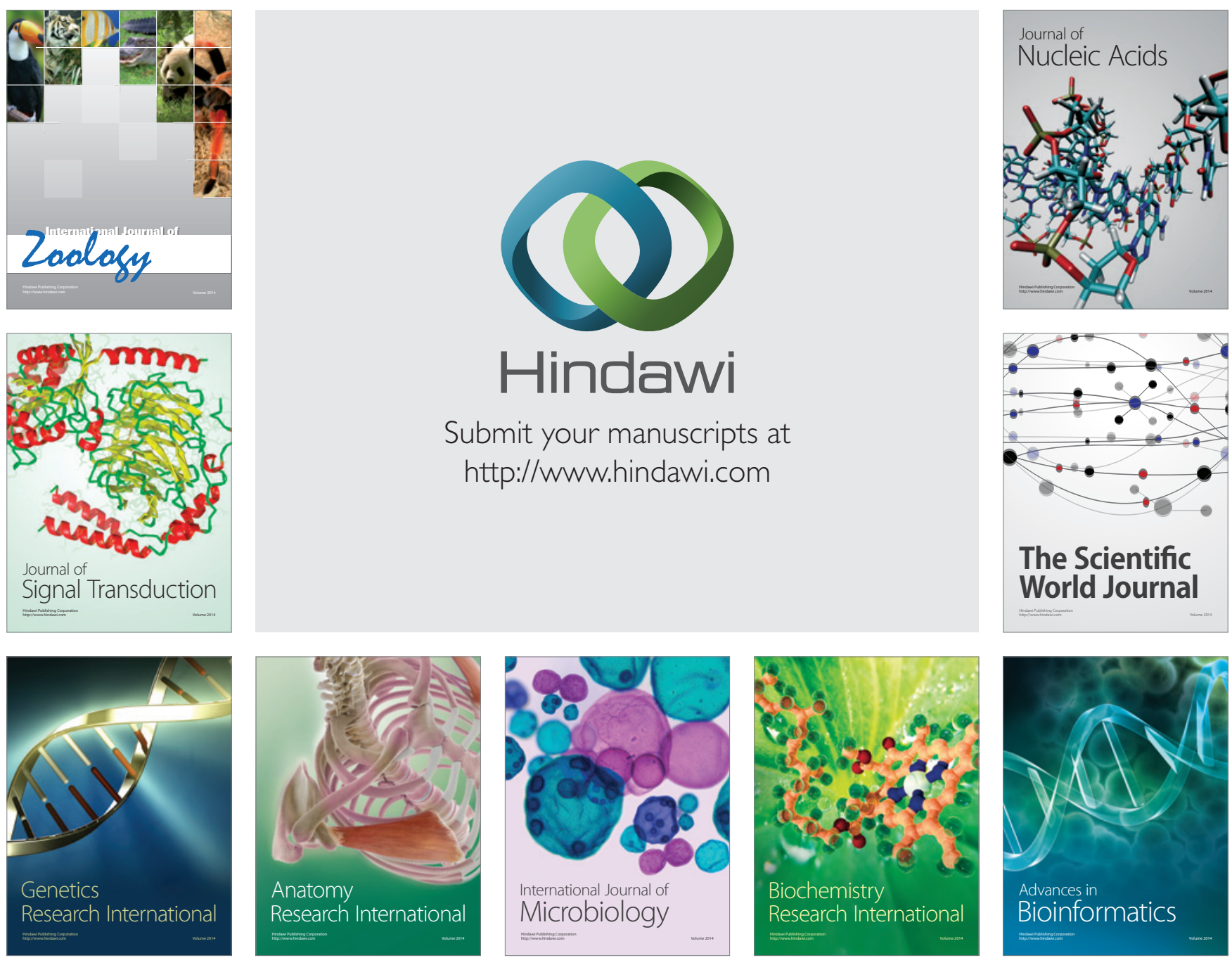

The Scientific World Journal
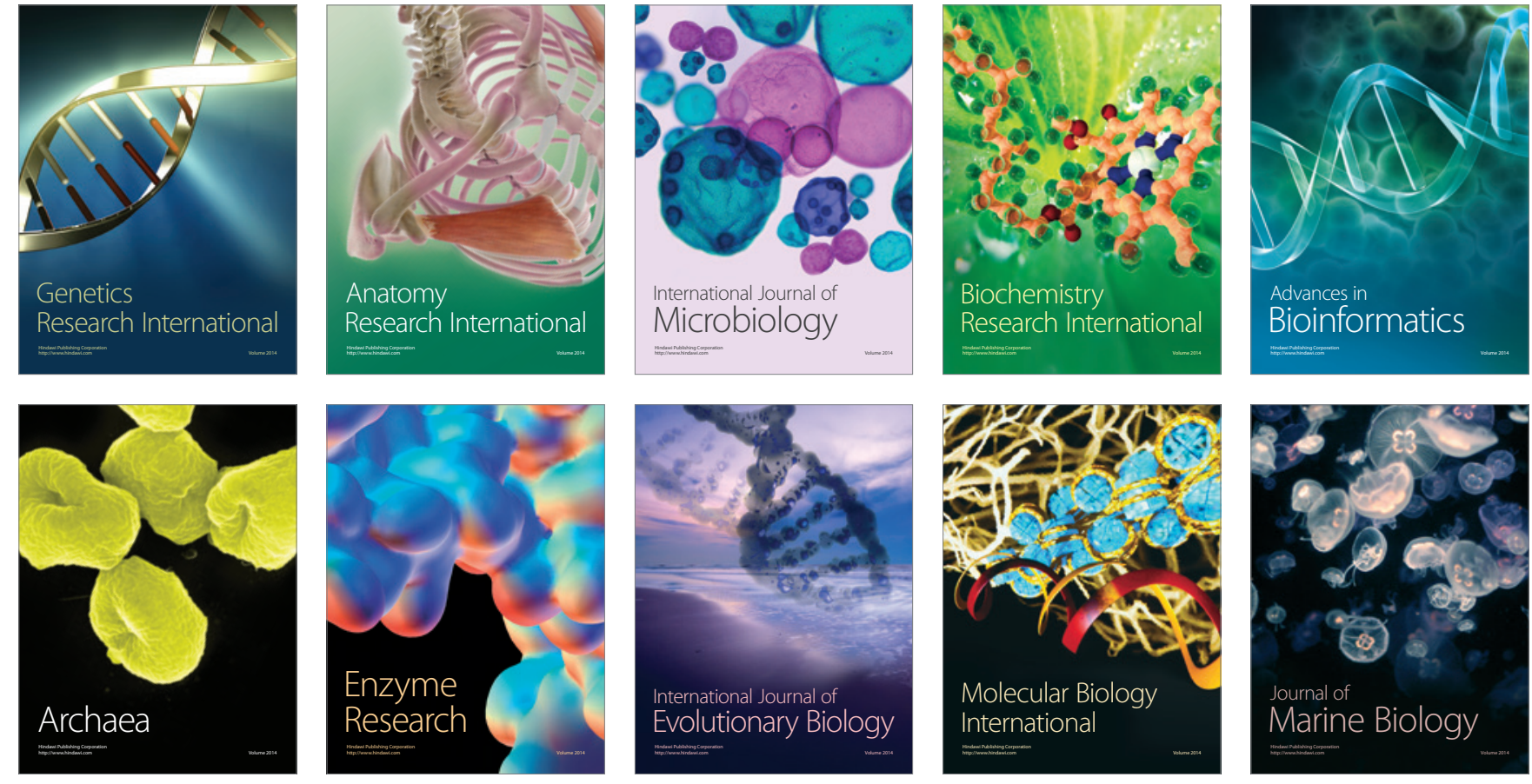